ISA

Arboriculture \& Urban Forestry 2015. 41(2): 103-109

\title{
Evaluation of Ash Tree Symptoms Associated with Emerald Ash Borer Infestation in Urban Forests
}

\author{
Anand B. Persad and Patrick C. Tobin
}

\begin{abstract}
The emerald ash borer (EAB), first discovered in North America in Michigan in 2002, continues to expand its distributional range. Early detection of EAB remains a major caveat in efforts to implement proactive management strategies. Past reports have shown that ash trees infested with EAB have an increased risk of branch failure and other symptoms associated with tree decline. Therefore, early detection efforts could be improved if a suite of tree symptoms-prior to visible signs of EAB infestation-can be identified. Researchers initiated a four-year study in Ohio, U.S. (2009-2012) to investigate and document symptoms associated with the EAB-ash tree complex in urban sites. The prior history of EAB at the study sites ranged from ash trees with no visible evidence of infestation to those that were infested for more than two years. In trees shown to be recently colonized by EAB, visible signs of infestation, such as adult emergence holes, presence of EAB galleries, bark loss, and canopy loss were not always apparent. However, in EAB-positive trees, there was a significant tendency for the presence of cracks in scaffold branches, branch fractures within the upper canopy, and branch fractures specifically located closer to the union with the stem as opposed to at the branch tip or at the branch's center of gravity. This study highlights tree symptoms associated with the initial colonization of EAB when host trees are still apparently healthy, which could greatly facilitate future detection efforts for EAB.

Key Words. Agrilus planipennis; Arboriculture; Ash; Branch Fracture; Early Detection; Emerald Ash Borer; Fraxinus; Invasive Species; Scaffold Crack; Urban Forestry.
\end{abstract}

Emerald Ash borer (EAB) (Agrilus planipennis Fairmare) was discovered in North America in 2002 in Michigan (United States) and Ontario (Canada) (Cappaert et al. 2005; Poland and McCullough 2006), and is now expanding its distributional range throughout the range of ash in North America. Economic costs associated with $\mathrm{EAB}$ are projected to exceed USD $\$ 10$ billion in the U.S. (Kovacs et al. 2010), while a conservative estimate of the cost to Canadian municipalities exceeds USD $\$ 800$ million (McKenney et al. 2012). It is believed that $\mathrm{EAB}$ has the potential to virtually eliminate ash as a component of North American forests, with direct and indirect effects to ecosystem processes and plant and animal communities (Cappaert et al. 2005; Gandhi and Herms 2010; Pugh et al. 2011).

The spectrum of management tactics for $\mathrm{EAB}$ currently varies from 'no action' to 'aggressive management, which involves the selective removal of dead and declining ash while remaining ash trees are chemically treated-especially in urban forests (McCullough and Mercader 2012; McKenney and Pedlar 2012; Vannatta et al. 2012). Because infestations can remain undetected for numerous years, the latter option relies heavily on successful early detection efforts for treatment to be optimally effective. Early detection efforts in forested stands and naturally seeded woodlots often incorporate the use of girdled, sentinel ash trees, which, along with branch sampling and debarking (Ryall et al. 2011), is extremely labor intensive and destructive. In managed urban trees, other detection efforts may include monitoring through deployed traps, which are currently not sensitive enough to consistently detect initial EAB populations (Cappaert et al. 2005; McCullough et al. 2009; Francese et al. 2010; Poland et al. 2011). Due to the limitations of the currently available tools to detect $\mathrm{EAB}$, most new infestations 
are thought to be several years old by the time they are detected. Confirmed EAB presence is associated with D-shaped exit holes, heavy dieback and epicormic branching, and S-shaped, frass-filled larval tunneling. However, detection at this stage is often too late for chemical or biological treatments to be effective. For example, current management guidelines suggest that if the tree has lost more than 50\% of its canopy due to EAB, treatments aimed to save the tree are not likely to be successful (Herms et al. 2009). Instead, reactive measures, such as tree removal, are the only remaining management option.

Tunnels formed by all larval stages of EAB occur under the bark and are confined to the greater cambium region where they feed primarily on phloem and outer xylem (Siegert et al. 2010). At initial colonization densities, an infestation is often cryptic because visual cues are limited as the bark remains intact. Canopy loss may not occur until EAB infestations intensify. However, as early as one to two years following colonization, internal, and hence anthropogenically unapparent damage due to larval tunneling results in significantly lower levels of moisture, ultimately degrading the structure and material properties of ash (Persad et al. 2013). Prior research has also shown that branches after static loading failed closer to the union with the stem in trees infested with EAB in both early and advanced infestations (Persad et al. 2013). Unfortunately, static loading to branch failure is not a practical tool in early detection efforts. However, the natural dismantling and failure of branches or stems of EAB infested trees could occur from other sources, such as wind, rain, and snow, and thus potentially provide detection cues.

Documented symptoms associated with EAB infestations could include woodpecker induced bark flaking, canopy thinning, D-shaped exit holes, and the presence of epicormic shoots. Apart from the D-shaped exit holes, which are unlikely to be caused by another insect, all associated symptoms could arise from causative agents other than EAB. To help improve detection capabilities to the urban forester, researchers initiated a visual survey to gather data on natural dismantling and effects from early larval tunneling on EAB-infested trees. The main objective was to identify and correlate observable symptoms associated with EAB infestation prior to canopy thinning and other potential cues that would be anthropogenically apparent prior to the documented late-infestation signs of EAB, such as bark flaking, EAB exit holes. These additional visual effects if identified would be very valuable especially for workers in managed urban settings to be able to detect EAB before canopy loss and dieback begin.

\section{MATERIALS AND METHODS}

Researchers initiated a survey in 2009 to quantify symptoms that are typically associated with the EAB-ash tree complex. Visual, non-destructive surveys were conducted from late June (after emergence of EAB) through August each year between 2009 and 2012 in northern Ohio, U.S. Selected sites were in and around the cities of Perrysburg, Sylvania, Toledo, Cleveland, Strongsville, Shalersville, and Kent, Ohio. Sites selected included those that were in the most recent regulated area (USA Code of Federal Regulations, Title 7, Chapter III, Part 301.53), had recorded $E A B$ activity for the first time at the time of study, or were known to be infested for at least two years. Green ash (Fraxinus pennsylvanica Marsh) was surveyed along arterial roadways, city/ county rights-of-way in residential areas, and park and woodlot settings. Prior to the survey, and after consultation with the relevant management agencies of the properties where the survey was conducted, it was determined that no trees selected for the survey had been chemically treated, either proactively or curatively, for EAB. A total of 719 trees were inspected across all four years, and ranged from 2.5 to $142.2 \mathrm{~cm}$ diameter at breast height (DBH) (Figure 1).

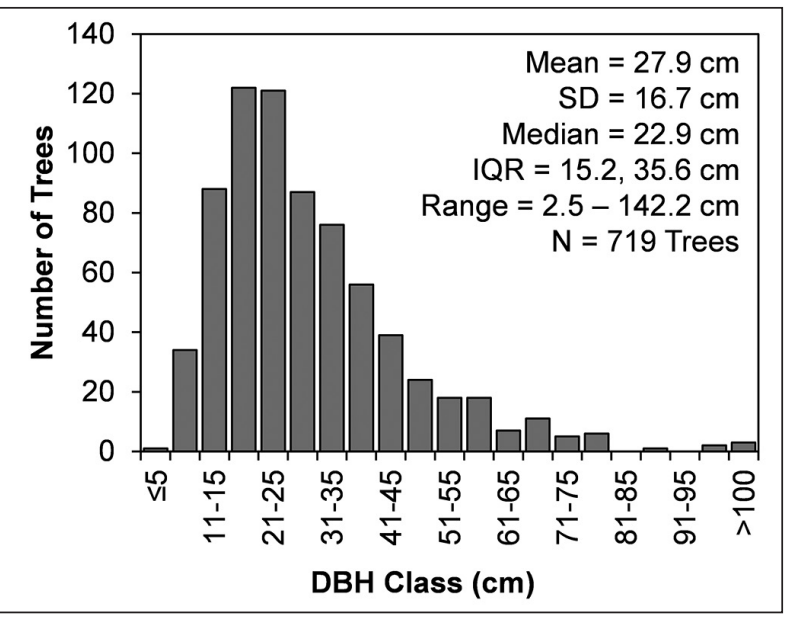

Figure 1. Distribution of DBH among 719 green ash (Fraxinus pennsylvanica Marsh) trees sampled in this study, 20092012. 
As part of our sample design, we placed each sampled tree into one of three categories. Level I trees were visually determined to be uninfested but within $0.5 \mathrm{~km}$ of a known infested tree $(\mathrm{N}=$ 387 trees); these trees could be considered as either negative or false negative for EAB. Level II trees were apparently infested for $1-2$ years $(\mathrm{N}=288$ trees) and visually symptomatic with the presence of characteristic D-shaped adult emergence holes or frass-filled serpentine tunneling, if the tree was exposed due to bark loss. Level III trees were known to be infested for $>2$ years ( $\mathrm{N}=44$ trees); some of these trees had already been marked for removal due to EAB. Infestation records for both Level II and III trees were based on information from local authorities, land managers, county extension agents, landowners, and state and federal records.

For each tree surveyed, researchers recorded several signs and symptoms that are already associated with the presence of EAB (Table 1). The proportion of canopy thinning or loss was determined by estimating lost foliage from branches in relation to a full canopy (Smitley et al. 2008). Researchers also noted the presence of epicormic branching, bark loss, and cracks in scaffold branches. Trees were thoroughly inspected for the presence of distinctive $\mathrm{EAB}$ galleries and exit holes from the basal area up the stem and as far up as possible (to at least $2 \mathrm{~m}$ ) and including the first scaffold branch if it occurred within that height.

The stem was also divided into three sections (lower, middle, and upper third); the presence of branch fractures was noted. Because branches that fail leave stubs behind, the length of the remaining branch portion was also used to estimate the fracture point location on the branch. The fracture point was placed into one of three categories: 1) a collar breakpoint, if failure occurred near the union with the stem; 2) a center of gravity breakpoint, if branch failure occurred leaving a stub at least one-third the length of the branch; and 3) a tip, if the fracture occurred beyond the center of gravity and closer to one-third the distal end of the branch. Each tree was inspected from the ground in four cardinal directions and from a distance that gave full view of the tree.

Statistical analyses were conducted using the epicalc package (Chongsuvivatwong 2012) in $R$ ( $R$ Development Core Team 2012). In the epicalc package, researchers estimated the risk ratio and corresponding $95 \%$ confidence intervals (CI) of a specific symptom being associated with trees in which $\mathrm{EAB}$ was positively detected relative to trees in which $\mathrm{EAB}$ was not positively detected. A risk ratio whose confidence intervals include 1 would not indicate a significant association, as it would imply that the symptom is associated with trees that are both positively or not positively identified as an EAB-infested tree. This statistical approach is analogous to epidemiological studies that address, for example, commonality in foods consumed within a population, in which some individuals succumb to a food-borne outbreak. Thus, the use of this approach allowed the study authors to develop a set of symptoms that were likely to be associated with trees that ultimately were shown to be infested with EAB (from an anthropogenic perspective) without quantifying the conditional probability of infestation given a symptom or suite of symptoms, which would be challenging given the potentially high rate of $\mathrm{EAB}$ false negatives.

Table 1. Host tree symptoms and recorded values.

\begin{tabular}{ll}
\hline Symptom & Values \\
\hline Bark loss & Presence or absence \\
Epicormic branching & Presence or absence \\
Canopy loss (\%) & $0 \%-100 \%$ \\
Scaffold crack & Presence or absence \\
Location of fractured branch & No fractured branch, lower one-third, \\
& middle third, or upper third \\
Fracture point & Collar, center of gravity, or branch tip \\
\hline
\end{tabular}

\section{RESULTS}

The presence of bark loss (risk ratio $=2.7 ; 95 \% \mathrm{CI}$ $=2.3,3.2$ ) and scaffold cracks (risk ratio $=2.5 ; 95 \%$ $\mathrm{CI}=2.2,2.9)$ were both significantly associated with trees positively identified with $\mathrm{EAB}$ (Figure $2 \mathrm{~A}$; Figure 2B). In addition, branch fractures only within the upper one-third of the canopy (risk ratio $=1.5,95 \% \mathrm{CI}=1.2,1.9)$ were significantly associated with trees positively identified with $\mathrm{EAB}$, while branch fractures in the lower third of the canopy (risk ratio $=0.7,95 \% \mathrm{CI}=0.5,0.9$ ) were significantly associated with trees that were not positively identified with EAB (Figure 2C). Branch fractures in the middle third of the canopy (risk ratio $=1.2$; $95 \% \mathrm{CI}=0.9,1.5)$, or the absence of branch fractures (risk ratio $=1.0 ; 95 \% \mathrm{CI}=0.9,1.1$ ), were not significantly associated with either trees positively identified with $\mathrm{EAB}$ or not (risk ratio $=1.2 ; 95 \% \mathrm{CI}$ $=0.9,1.5)$. Lastly, branch fractures located closer to the union with the stem were significantly associated with trees positively identified with $\mathrm{EAB}$ (risk 
ratio $=1.7 ; 95 \% \mathrm{CI}=1.4,2.1$, while branch fractures at the branch tip were significantly associated with trees that were not positively identified with $\mathrm{EAB}$ (risk ratio $=0.7 ; 95 \% \mathrm{CI}=0.5,0.9)($ Figure $2 \mathrm{D})$. The absence of branch fractures (risk ratio $=0.9 ; 0$; $95 \% \mathrm{CI}=0.7,1.1)$, and branch fractures at the center of gravity (risk ratio $=1.0 ; 95 \% \mathrm{CI}=0.6,1.4$ ), were not significantly associated with EAB detection.

It is noteworthy that researchers failed to detect a significant effect of the proportion of canopy loss (risk ratio $=1.0 ; 95 \% \mathrm{CI}=0.9,1.1$ ), and the presence of epicormic branching (risk ratio $=1.1$; $95 \% \mathrm{CI}=0.8,1.4)$. Both are generic indicators of tree decline from various stress agents, including EAB. Because many of the selected trees, due to the objective of the study, were visually uninfested or only thought to be recently infested (i.e., Level I or II), trees had not yet formed epicormic branching that is typical of trees heavily infested with $\mathrm{EAB}$ (McCulloughetal.2008).Indeed, although epicormic

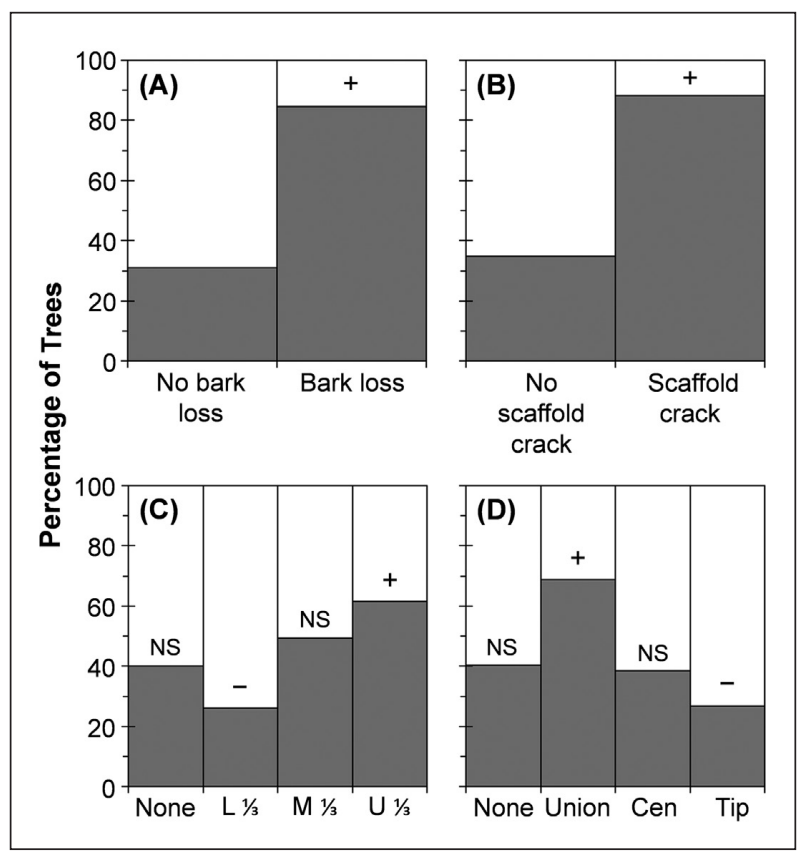

Figure 2. Mosaic plots of the percentage of trees where EAB was positively identified (grey bars) or not positively identified (white bars) based on the absence or presence of (A) bark loss or (B) scaffold cracks; (C) absence or presence of branch fractures within the lower (L), middle (M), or upper (U) one-third of the canopy; and (D) the location of the fracture point of the branch, if present: at the union with the stem (Union), branch center of gravity (Cen), or branch tip (Tip). Positive and negative symbols indicate those symptoms that were significantly positively or negatively associated with the EAB-ash tree complex, respectively, while NS indicates no significant association. branching was observed in 158 trees in which EAB was positively identified, researchers also observed 174 trees with epicormic branching in which EAB was not positively identified, and 387 trees with no epicormic branching. Also, although noninfested trees tended to have little or no canopy loss, while high levels of canopy loss were mostly from infested trees, a number of infested trees were also detected in which little to no canopy loss was recorded (Figure 3). However, in a follow-up analysis on canopy loss, in which trees were placed into one of two categories: 1) trees in which the canopy loss was $\leq 30 \%$, and 2) trees in which the canopy loss was $>30 \%$, we detected a significant association; the presence of $>30 \%$ canopy loss was significantly associated with trees positively identified with $\mathrm{EAB}$ (risk ratio $=1.8 ; 95 \% \mathrm{CI}=1.5,2.1$ ).

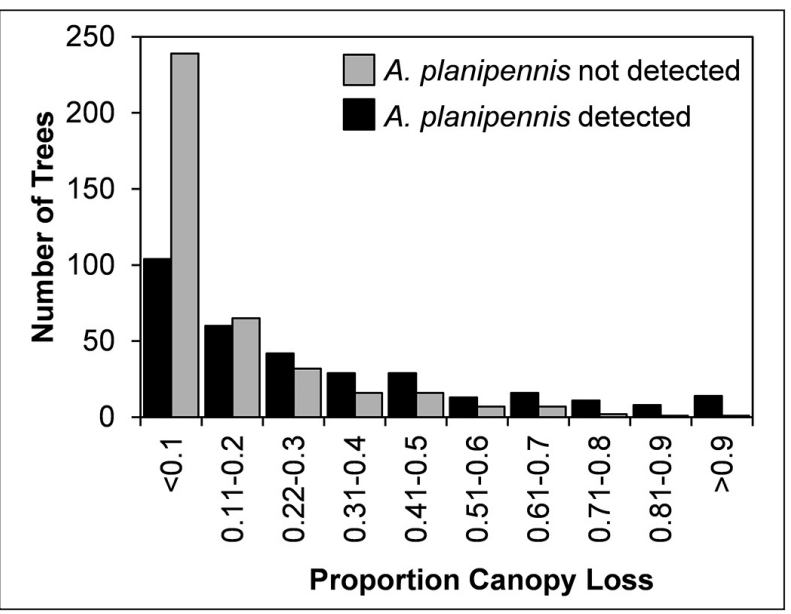

Figure 3. Distribution of the number of trees $(\mathrm{N}=719)$ by the proportion of canopy loss and whether EAB was visibly detected (i.e., trees that were either negative or false negative for EAB).

\section{DISCUSSION}

In this study, the authors relied on visual, ground surveys of a range of ash trees with different assumed histories of EAB infestation to determine the association of several tree symptoms with the $\mathrm{EAB}$-ash tree complex in urban systems. The overall objective was to determine if cues not previously known to be definitively associated with EAB could be useful in early detection efforts for urban foresters and municipal arborists. The study authors contend that these findings should be of use to arborists and other tree workers in identifying EAB-infested trees prior to the associated obvious symptoms, including ash tree canopy thinning and eventual 
tree mortality. Also, due to the dangers of tree removal, especially with unexpected branch failure due to EAB-weakened trees (Persad et al. 2013), these findings could also factor into safety programs associated with working with EAB-infested ash trees.

Early detection is a crucial component of invasive species management, especially in eradication programs (Epanchin-Niell et al. 2012; Pluess et al. 2012; Tobin et al. 2014), yet is often the major caveat to effectively planning and implementing proactive strategies due to the lack of sensitive tools for monitoring the invading species (Government Accountability Office 2006; Liebhold and Tobin 2008). This is particularly relevant to the EAB-ash tree complex, as ash trees with low densities of $\mathrm{EAB}$ often exhibit virtually no external symptoms of an infestation (Siegert et al. 2010). Consequently, false negatives for $E A B$ are a major obstacle in its management. Definitive sampling for EAB often requires destructively sampling a tree, which is labor intensive and renders subsequent implementation of management strategies to protect the tree as superfluous. Although the results of this study do not contribute to resolving the challenge of false negatives, these findings-such as association of scaffold cracks and branch failures close to the collar with the early stages of EAB infestation prior to canopy thinning-could supplement other survey tools that are currently available, including tree girdling and monitoring traps (Cappaert et al. 2005; Poland and McCullough 2014). Collectively, the combination of various detection tools enables practitioners to optimize EAB sampling efforts. A combination of visual techniques followed by branch collection and debarking (Ryall et al. 2011) could improve labor and time considerations, particularly in large-scale sampling situations. Such efforts are important in spatially extensive surveys aimed at detecting EAB early enough that proactive mitigating control tactics might be used.

Proactive management strategies, including effective Plant Health Care (e.g., pruning, treating with an approved product, supplemental irrigation), enhanced by visual detection techniques, could additionally help in reducing the risks of ash tree failure associated with EAB infestation. Hauer et al. (1993) and Detters et al. (2008) indicated that risk may arise from any situation that introduces deadwood and compromises the structure and load-bearing integ- rity of trees. In both scenarios, EAB could be a contributing agent and thus poses additional safety risks to tree care professionals, urban foresters, and arborists. This study highlights the presence of symptoms associated with $\mathrm{EAB}$, including branch fractures in $\mathrm{EAB}$-infested trees and fractures located closer to the union with the stem in trees, which could precede canopy thinning and have not been previously documented to be associated with EAB infestation.

Acknowledgments. We thank Scott Kirby of the Davey Tree Experts Co. for help in setting up the survey sites along with Davey Institute research assistants Holli Stebnor, Michael Hannebique, and Sarrah Moskin who assisted in data gathering and processing. We are also grateful to Dr. Constance Hausman of Cleveland Metroparks for help in providing input and sites for evaluation. We also thank Dr. Dan Herms (The Ohio State University) for reviewing an earlier version of the manuscript. We also would like to express gratitude to two anonymous reviewers whose comments enhanced the manuscript.

\section{LITERATURE CITED}

Cappaert, D., D.G. McCullough, T.M. Poland, and N.W. Siegert. 2005. Emerald ash borer in North America: A research and regulatory challenge. The American Entomologist 51:152-165.

Chongsuvivatwong, V. 2012. Package 'epicalc'. Accessed 08/11/2014. <http://cran.r-project.org/web/packages/epicalc/epicalc.pdf>

Detters, A., C. Cowell, L. McKeown, and P. Howard. 2008. Evaluation of current rigging and dismantling practices used in arboriculture. Research Report 668 of the Health and Safety Executive and the Forestry Commission. Norwich, England, UK. 355 pp.

Epanchin-Niell, R.S., R.G. Haight, L. Berec, J.M. Kean, and A.M. Liebhold. 2012. Optimal surveillance and eradication of invasive species in heterogeneous landscapes. Ecology Letters 15:803-812.

Francese, J.A., D.J. Crook, I. Fraser, D.R. Lance, A.J. Sawyer, and V.C. Mastro. 2010. Optimization of trap color for the emerald ash borer, Agrilus planipennis (Coleoptera: Buprestidae). Journal of Economic Entomology 103:1235-1241.

Gandhi, K.J.K., and D.A. Herms, 2010. North American arthropods at risk due to widespread Fraxinus mortality caused by the alien emerald ash borer. Biological Invasions 12:1839-1846.

Government Accountability Office. 2006. Invasive forest pests. Lessons learned from three recent infestations may aid in managing future efforts. Report GAO-06-353 to the Chairman, Committee on Resources, House of Representatives. Washington, D.C., U.S. 125 pp.

Hauer, R.J., W. Wing, and J.O. Dawson. 1993. Ice storm damage to urban trees. Journal of Arboriculture 19:187-193.

Herms, D.A., D.G. McCullough, D.R. Smitley, C. Sadof, R.C. Williamson, and P.L. Nixon. 2009. Insecticide options for protecting ash trees from emerald ash borer. North Central IPM Center Bulletin (second edition). Ohio State University Extension, Wooster, Ohio, U.S. 12 pp.

Kovacs, K.F., R.G. Height, D.G. McCullough, R.J. Mercader, N.W. Siegert, and A.M. Liebold. 2010. Cost of potential emerald ash borer damage in U.S. Communities, 2009-2019. Ecological Economics 69:569-578. 
Liebhold, A.M., and P.C. Tobin. 2008. Population ecology of insect invasions and their management. Annual Review of Entomology 53:387-408.

McCullough, D.G., N.F. Schneeberger, and S.A. Katovich. 2008. Pest alert (revised). Emerald ash borer. Pest Report NA-PR-02-04 2004. United States Department of Agriculture, Forest Service, Northeastern Area, State and Private Forestry. Washington, D.C. 2 pp.

McCullough, D.G., T.M. Poland, and D. Cappaert. 2009. Attraction of the emerald ash borer to ash trees stressed by girdling, herbicide, and wounding. Canadian Journal of Forest Research 39:1331-1345.

McCullough, D.G., and R.J. Mercader. 2012. Evaluation of potential strategies to SLow Ash Mortality (SLAM) caused by emerald ash borer (Agrilus planipennis): SLAM in an urban forest. International Journal of Pest Management 58:9-23.

McKenney, D.W., and J.H. Pedlar. 2012. To treat or remove: An economic model to assist in deciding the fate of ash trees threatened by emerald ash borer. Arboriculture \& Urban Forestry 38:121-129.

McKenney, D.W., J.H. Pedlar, D.Yemshanov, D.B. Lyons, K.L. Campbell, and K. Lawrence. 2012. Estimates of the potential cost of emerald ash borer (Agrilus planipennis Fairmaire) in Canadian Municipalities. Arboriculture \& Urban Forestry 38:81-91.

Persad, A.B., J. Siefer, R. Montan, S. Kirby, O.J. Rocha, A.W. Jones, C. Ranger, and M. Redding. 2013. Effects of emerald ash borer on the structure and material properties of ash trees. Arboriculture \& Urban Forestry 39:11-16.

Poland, T.M., and D.G. McCullough. 2006. Emerald ash borer: invasion of the urban forest and the threat to North America's ash resource. Journal of Forestry 104:118-124.

Poland, T.M., D.G. McCullough, and A.C. Anulewicz. 2011. Evaluation of an artificial trap for Agrilus planipennis (Coleoptera: Buprestidae) incorporating olfactory and visual cues. Journal of Economic Entomology 104:517-531.

Poland, T.M., and D.G. McCullough. 2014. Comparison of trap types and colors for capturing emerald ash borer adults at different population densities. Environmental Entomology 43:157-170.

Pluess, T., V. Jarošík, P. Pyšek, R. Cannon, J. Pergl, A. Breukers, and S. Bacher. 2012. Which factors affect the success or failure of eradication campaigns against alien species? PLoS ONE $7:$ e48157.
Pugh, S.A., A.M. Liebhold, R.S. Morin. 2011. Changes in ash tree demography associated with emerald ash borer invasion, indicated by regional forest inventory data from the Great Lakes states. Canadian Journal of Forest Research 41:2165-2175.

Ryall, K.L., J.G. Fidgen, and J.J. Turgeon. 2011. Detectability of the emerald ash borer (Coleoptera: Buprestidae) in asymptomic urban trees using branch samples. Environmental Entomology 40:679-688.

Siegert, N.W., D.G.McCullough, D.W. Williams, L. Fraser, T.M. Poland, and S.J. Pierce. 2010. Dispersal of Agrilus planipennis (Coleoptera: Buprestidae) from discrete epicenters in two outlier sites. Environmental Entomology 39:252-265.

Smitley, D., T. Davis, and E. Rebek. 2008. Progression of ash canopy thinning and dieback outward from the initial infestation of emerald ash borer (Coleoptera: Buprestidae) in southeast Michigan. Journal of Economic Entomology 101:1643-1650.

Tobin, P.C., J.M. Kean, D.M. Suckling, D.G McCullough, D.A. Herms, and L.D. Stringer. 2014. Determinants of successful arthropod eradication programs. Biological Invasions 14:401-414.

Vannatta, A.R., R.H. Hauer, and N.M. Schuettpelz. 2012. Economic analysis of emerald ash borer (Coleoptera: Buprestidae) management options. Journal of Economic Entomology 105:196-206.

\author{
Anand B. Persad (corresponding author) \\ Davey Institute \\ 1500 N. Mantua Street \\ Kent, Ohio 44240, U.S. \\ apersad@davey.com \\ Patrick C. Tobin \\ Forest Service \\ U.S. Department of Agriculture \\ Northern Research Station \\ 180 Canfield Street \\ Morgantown, West Virginia 26505-3101, U.S. \\ University of Washington \\ School of Environmental and Forest Sciences \\ Box 352100 \\ Seattle, WA 98195-2100, U.S.
}


Résumé. L'agrile du frêne (AF) fût découverte pour la première fois en Amérique du Nord dans le Michigan en 2002 et depuis, continue d'étendre son aire de répartition. La détection précoce de l'agrile du frêne est l'élément déclencheur pour la mise en place de stratégies de gestion proactives. Des rapports antérieurs ont démontré que les frênes infestés par l'agrile présentent un risque accru de chute de branches et de l'apparition d'autres symptômes associés au dépérissement des arbres. Par conséquent, les efforts de détection précoce pourraient être améliorés si une séquence de déficiences symptomatiques-préalables à l'apparition de symptômes spécifiques à l'agrile-pouvaient être identifiés. Les chercheurs ont entrepris une étude qui s'est étalée sur quatre années dans l'Ohio, aux États-Unis (2009-2012) visant à enquêter et documenter les symptômes associés à l'agrile du frêne en milieu urbain. L'historique des sites en lien avec l'AF consistait en frênes ne montrant aucun signe visible d'infestation jusqu'à d'autres frênes infestés depuis plus de deux ans. Dans les arbres qui avaient été récemment colonisés par l'agrile du frêne, des signes visibles d'infestation tels que des trous de sortie des adultes, la présence de galeries d'AF, le décollement d'écorce et le déclin progressif du feuillage dans le houppier nétaient pas toujours apparents. Cependant, les frênes infestés par l'agrile affichaient des fissures dans les branches charpentières, des branches cassées dans le houppier supérieur et des bris de branches davantage localisés à proximité du tronc plutôt que près de l'extrémité des branches ou à mi-chemin le long de celles-ci. Cette étude met en évidence les symptômes associés à la colonisation initiale de l'agrile du frêne lorsque les arbres hôtes sont encore en bonne santé apparente, ce qui pourrait grandement faciliter les efforts futurs de détection de l'agrile du frêne.

Zusammenfassung. Der Glänzende Eschenbohrer EAB, welcher erstmals in Nordamerika in Michigan in 2002 entdeckt wurde, expandiert kontinuierlich seinen Verbreitungsradius. Das frühe Erkennen von EAB bleibt eine Hauptvorsichtsmaßnahme in den Bemühungen, proaktive Managementstrategien zu implementieren. Vergangene Berichte haben gezeigt, dass befallene Eschen ein großes Risiko an Astversagen und anderen Symptome, die mit Baumversagen assoziiert sind, haben. Daher können die Bemühungen des frühen Erkennens verbessert werden, wenn eine Anzahl von Baumsymptomen - vor den ersten sichtbaren Zeichen eines

EAB-Befalls - identifiziert werden. Wissenschaftler initiierten eine vierjährige Studie in Ohio (2009-2012) um Symptome in Verbindung mit dem EAB-Eschen-Komplex in urbanen Räumen $\mathrm{zu}$ untersuchen und zu dokumentieren. Die vorangegangene Historie von EAB an den Studienstandorten rangierte von Bäumen mit keinen sichtbaren Anzeichen von Befall bis hin zu solchen, die seit mehr als zwei Jahren befallen waren. In Bäumen, die erst kürzlich mit EAB kolonisiert wurden, waren sichtbare Anzeichen des Befalls, so wie Aufschlupflöcher adulter Bohrer, Anwesenheit von Bohrgallerien, Borken- und Kronenverluste, nicht immer gegenwärtig. Dennoch waren in EAB-positiven Bäumen eine signifikante Tendenz für das Auftreten von Rissen in den Kronenleitästen , Astbrüche in der oberen Krone und Astbrüche, die besonders dicht an der Astgabel auftraten in Gegensatz zu der Astspitze oder dem Astmittelpunkt. Die Studie beleuchtet Baumsymptome in Verbindung mit der ersten Kolonisation von EAB, wenn die Wirtsbäume noch gesund erscheinen, was die künftige Auffindung von EAB stark unterstützt.

Resumen. El barrenador esmeralda del fresno (BEF), por primera vez descubierto en Michigan en 2002, continúa ampliando su área de distribución. La detección temprana de BEF sigue siendo una advertencia importante en los esfuerzos para poner en práctica estrategias de gestión proactiva. Los informes anteriores han demostrado que los fresnos infestados con BEF tienen un mayor riesgo de fracaso de ramas y otros síntomas asociados con la declinación de árbol. Por lo tanto, los esfuerzos de detección temprana podrían mejorarse si se identifican un conjunto de síntomas anteriores de los árboles, signos visibles de infestación por BEF. Los investigadores iniciaron un estudio de cuatro años en Ohio, Estados Unidos (2009-2012) para investigar y documentar los síntomas asociados con el complejo árbol - EAB en sitios urbanos. La historia previa de $\mathrm{BEF}$ en los sitios de estudio varió de fresnos sin evidencia visible de la infestación a los que se infestaron por más de dos años. En los árboles que muestran colonización reciente por BEF, los signos visibles de infestación, como agujeros de emergencia de adultos, la presencia de galerías de BEF, pérdida de corteza y la pérdida del dosel no siempre fueron evidentes. Sin embargo, en los árboles positivos a BEF, hubo una tendencia significativa a la presencia de grietas en las ramas estructurales, fracturas de ramas en el dosel superior y fracturas de ramas específicamente cerca de la unión con el tallo o en el centro de la gravedad de la rama. Este estudio pone de manifiesto los síntomas de los árboles asociados con la colonización inicial de $\mathrm{EAB}$ cuando los árboles hospederos están aparentemente sanos, lo que podría facilitar en gran medida los esfuerzos de detección de futuro para BEF. 